\title{
The “Bogus" Refugee: Roma Asylum Claimants and Discourses of Fraud in CANada's Bill C-31
}

\author{
Petra Molnar Diop
}

\begin{abstract}
The passage of Bill C-31 into Canadian law in June 2012 is part of a discourse created around refugees by the current Government of Canada. Refugees are divided into "good and proper" refugees who live in camps abroad, and the "fraudulent and bogus" refugees who claim asylum at the Canadian border. The new act, Bill C-31 or Protecting Canada's Immigration System Act, is analyzed with respect to changes that will result in the systematic exclusion of certain groups of asylum seekers from Canada, based on these discourses of "bogus" and "fraud," even though these groups may include genuine refugees. Drawing on the case of Czech Roma refugee claimants who come to Canada from Europe, this article shows how the Roma come to stand for the perfect "bogus" refugee-a person who wants to cheat the benevolent Canadian system without having grounds for a successful refugee status application. A critical look at the legislation provides new insights into the relations between governmentality and the regimes of citizenship, with the state performing its power in increasingly spectacular ways. Refugees act as the abject Other that legitimizes, legalizes, and reaffirms such state interventions.
\end{abstract}

\begin{abstract}
Résumé
L'adoption du projet de loi C-31 en juin 2012 fait partie d'un discours créé par le gouvernement actuel du Canada autour des réfugiés. Ceux-ci sont divisés en «bons et justes " réfugiés qui vivent dans des camps à l'étranger et réfugiés «bidon et frauduleux» qui demandent l'asile à la frontière canadienne. La nouvelle loi, le projet de loi C-31 ou Loi visant à protéger le système d'immigration du Canada, est analysée en fonction de changements qui se traduiront par l'exclusion systématique du Canada de certains groupes de demandeurs d'asile, sur la base de ces notions de "bidon" et «fraude», même si ces groupes peuvent comprendre de véritables réfugiés. S'appuyant sur le cas de demandeurs d'asile roms tchèques venus d'Europe au Canada, cet article montre comment les Roms en viennent à incarner le réfugié «bidon" idéal - quelqu’un qui veut abuser de la bienveillance du système canadien en déposant une demande de statut de réfugié sans fondement. Un regard critique sur le projet de loi apporte un nouvel éclairage sur les relations entre la gouvernementalité et les régimes de citoyenneté, où l'état exerce son pouvoir de façon de plus en plus spectaculaire. Le réfugié tient lieu d'Autre abject qui légitime, légalise, et réaffirme les interventions de l'État.
\end{abstract}




\section{Introduction}

The recent changes made to Canada's refugee determination system and the hardening of attitudes toward refugees has placed certain asylum seekers squarely at the forefront of nation-building projects. By equating refugees with "the Other," the figure of the asylum seeker becomes the vehicle through which the performance of sovereignty can be enacted, as the state promulgates a particular discourse about those who appear to be threatening state borders. This article examines the discourses that have been circulated about refugee claimants by the current Conservative Government of Canada and how such discourses create a binary between the "good" refugees who remain in refugee camps until they are brought to Canada as governmentassisted refugees (GARs), and the bad or "bogus" refugees who autonomously arrive at Canada's shores, seeking asylum of their own volition. ${ }^{1}$ This dichotomy is used to bolster the rhetoric of the benevolent and welcoming Canadian refugee system trying to cope with "fraudulent" asylum claimants clogging the process. The February 2012 introduction and December 2012 implementation of Bill C-31, fully named The Act to Amend the Immigration and Refugee Protection Act, the Balanced Refugee Reform Act, the Marine Transportation Security Act and the Department of Citizenship and Immigration, is in line with the worldwide trend toward the securitization of asylum and the enhanced policing of borders. In order to illustrate these discourses and their impact on a particular group of asylum seekers, it is useful to consider how Roma refugee claimants have been systematically presented as the embodiment of bogus refugees and denied refugee status.

For the purposes of this article, the designations Roma and Romani will be used, as they are generally seen as a selfappointed term by the Roma community in Canada. The term refugee must also be used critically. I examine the treatment of those who have self-identified as refugees in order to qualify for the Canadian refugee assessment process and have thus been designated as an entity that is treated in particular ways in Canadian immigration policy. Thus, I will be looking at Roma refugee claimants, not Roma refugees, in order avoid making judgments about whether or not they are bona fide refugees. The Roma are not geographically bounded, and in this article they are defined as a "group" based on their grounds for applying for refugee status in Canada as Czech nationals. I chose to focus on the Czech Roma in particular because their migration to Canada has been historically complicated by visa impositions. While their numbers are less than other groups of Roma who come to Canada seeking refugee status, the Czech Roma provide a representative subset of the population that has been seized on by the government and equated with being "bogus" and "fraudulent" refugees. While all Roma refugee claimants have been experiencing difficulties with the refugee determination system, the Czech Roma provide an interesting example of how government action against a particular group can crystallize in specific state mechanisms, such as visa imposition and safe-country lists. Czech Roma claimants come from a country deemed democratic and safe, a country seen as not "typically" producing refugees. They often abandon their refugee claim and either return to the Czech Republic or else enter another country in the European Union. Canada has also imposed numerous travel visas on the Czech Republic since the 1990s, in order to stem undesirable migration into Canada. ${ }^{2}$ Thus they are construed as the perfect "bogus" refugees-persons who want to cheat the benevolent Canadian system without having grounds for a successful refugee status application.

This article provides a brief history of the Roma in Europe, followed by a short analysis of the Canadian immigration and refugee regime. I then examine the recent changes made to Canadian legislation and statements by the government concerning the Roma that have been made to bolster these changes. This article argues that the utilization of such loaded terms as bogus and fraud is done deliberately to bolster state sovereignty as the refugee regime increasingly moves toward a "guilty until proven innocent" model, with any semblance of a fair refugee determination process transformed into an uncovering of those claimants who are "bogus" and out to cheat the benevolent Canadian system.

\section{Literature Review}

While there are studies on Roma migration in the European Union, such as in the United Kingdom, ${ }^{3}$ there are significant gaps in anthropological literature examining Roma populations in Canada. Broader literature concerning migration, in particular by Malkki, ${ }^{4}$ Clark-Kazak, ${ }^{5}$ Giles, ${ }^{6}$ Hyndman, ${ }^{7}$ and Winland ${ }^{8}$ orients our understanding of refugee issues, state sovereignty, and regimes of control. Further work has been done on state-sovereignty and discourse formation and the impacts of the practices of the sovereign nation on migrants and refugees. Billig ${ }^{9}$ examines the recurrent practices, banal routines, experiences, and discourses of the nation, and Gullestad ${ }^{10}$ analyzes how social imaginaries affect how the public thinks about collective societies and social values. Vertovec ${ }^{11}$ explores how identity is inherently tied to borders and their control. ${ }^{12}$ The particular regimes that have been employed to regulate migration have also been extensively explored, ${ }^{13}$ and while these particular mechanisms are beyond the scope of this article, it is important to note that border surveillance is inherently tied to projects of sovereignty. In Bill C-31, the ramped up surveillance and policing of borders is evident in the creation of 
the "irregular arrivals" category and the subsequent mandatory detentions for these claimants. ${ }^{14}$ The assemblages of knowledge that frame government interventions surrounding immigrants have also been explored by Blommaert. ${ }^{15}$ There are clear political reactions to the influx of migrants, and ideas of ethnicity and racialization impinge on the bodies of refugees and asylum seekers. ${ }^{16}$ Migrant identities and the relationships between migration, citizenship, and the state have been widely studied, ${ }^{17}$ and theorists such as Ahmed, Morris, Buck-Morss, Balibar, and Stewart and Harding ${ }^{18}$ explore the state responses to the affective impact of the refugee and alien figure. In this environment, certain language and symbols come to be used to mobilize concerns about foreigners, such as the formulation of the "bogus" or "fraudulent" refugee, which can be seen in the rhetoric surrounding Roma refugee claimants and Bill C-31. ${ }^{19}$

When examining the discourses around Roma migrants in particular, the works of linguist and Roma scholar Ian Hancock ${ }^{20}$ and Ronald Lee ${ }^{21}$ have been particularly helpful, as discourses surrounding the Roma population are historical. This particular population has been scapegoated and used in nation-making projects in Europe for centuries. In literature that concerns the Roma in Canada specifically from a social work perspective, Walsh and Krieg examine how Roma families are disadvantaged in numerous systems of governance, such as in social support. ${ }^{22}$ I show this to also hold true for systems of refugee determination systems. Butler's 2009 work foreshadowed the binary conceptualization for legitimate/illegitimate refugees in Canada and discussed the possible consequences of imposing "safe" country lists on Roma claimants, thus intensifying the notion that Roma are "bogus" refugees. ${ }^{23}$ There is also discussion of how increased ministerial discretion will affect Canadian refugee determination systems and how certain groups of refugees are seen as less deserving of having access to asylum adjudication. ${ }^{24}$ Liew in particular examines Canada's country-of-origin lists and the problematic consequences of "legitimate" refugee definition based on these lists. ${ }^{25}$ The perils of Canada's "safe lists" have also been examined. ${ }^{26}$ Kernerman shows how these forms of governance underlie Canada's motivations to keep certain populations from being able to access Canada's supposed humanitarian refugee policies through interdiction techniques and messages that only legitimate refugees are welcome. ${ }^{27}$ Dauverge in particular provides a thorough examination of how binaries are used in legal definitions by the state to filter certain populations out and keep migration in line with Western nationalist projects. ${ }^{28}$

This article builds on this lively debate and presents an analysis of what these "fraudulent claimant" discourses about the Roma can reveal about state power over citizens and non-citizens that is exerted by the sovereign state. Applying theories of state performativity to Bill C-31 shows how the persistent usage of the "bogus" refugee image bolsters the state's hard-line provisions in nation building projects. The figure of the immigrant poses a particular threat to the sovereign nation, ${ }^{29}$ yet it can also be used to justify increased intervention and securitization of the immigration and refugee regime. The discourses that surround Roma refugee claimants and the strength with which the designations of the "fraudulent" and "bogus" refugee stick to this particular group needs to be explored through the lens of discourse formation at the state level. Their promulgation through legislation, official statements, and media portrayals gives particular discursive formations their salience and truthfulness. ${ }^{30}$ Discourse formations work precisely because they shape people's realities, and their understanding of their and of the Others' place in the world. The perception of the public appears to be greatly influenced by policy and laws and the state portrayal of asylum seekers as "bogus" claimants whose "fraudulent" nature must be uncovered.

This is not to imply that consumers of public images are without agency and are blindly taken in by these discourses. Discourses are examined and reflected upon, yet their power lies precisely in their ability to constitute what is deemed to be the "truth." Rather than telling people how to behave, certain ideas become ingrained as the norm, especially if the discussion is framed as a matter of national security and protecting Canada from being fleeced by unwelcome and undesirable outsiders. When refugee claimants are presumed guilty of fraud and denied due process and fair refugee status determination, more bona fide claimants will be denied asylum. This new legislation will also arguably set a precedent for further conservative legislation affecting Canadian immigration policy and alter Canada's standing in international refugee law. A critical look at Bill C-31 provides insights into the relations between state sovereignty and the regimes of citizenship, with refugees acting as the abject Other that legitimizes, codifies, and reaffirms state interventions. With the notion of state sovereignty in flux, Western governments are increasingly turning to discourses of threat at the borders to justify increasingly hardline measures. By controlling the movement of citizen and non-citizen bodies, setting up systems of interdiction and increased security at the border, and dwelling on the need to protect fragile economies from invading outside forces, governments are able to bolster state sovereignty with the support of the majority of the citizen-subject populace under the "truth" that this is justified and for the greater good of the weakened nation-state. In examining the power relations surrounding refugee claimants and their treatment 
in state discourse, this article hopes to insert itself into the important debates surrounding the precarity of state sovereignty and the regimes of truth and power that modern states employ in order to strengthen their projects of control.

\section{From "Gypsy" to "Roma": Brief History of the Roma in Europe and Canada}

The term Roma is often overused and it can homogenize a varied population whose movements have spanned the globe over the centuries. The Roma are not a unified group, and some argue that there are four distinct groups: the Kalderash, Machvaiya, Churaria, and Lovara "who share the Romanes language [but] differ in customs, beliefs, traditional laws and ceremonies." 31 While there is much dissent about and criticism of the all-encompassing label Roma ${ }^{32}$ it has been adopted by many Roma as an identity marker over the other widely used and often derogatory terms such as Gypsy or Czigan. ${ }^{33}$

The Roma expanded out of India and into Europe in the 11th century following the expansion of the Ghaznavid Empire. For nearly as long as the Roma have moved out of India and entered Europe, they have endured widespread persecution and systematic racism and, as some authors and activists argue, "based on the definitions produced by the Geneva Convention Relating to the Status of Refugees in $1951,{ }^{34}$ the treatment of Roma in Europe is characterized by an egregious racism clearly recognizable as systemic in nature and thus qualifies them as refugees." 35 Indeed, Roma persecution is not an isolated, present-day phenomenon, and European history is replete with examples of systematic persecution and racism. In 16th-century Britain, Roma travellers faced abuse and ill-treatment, ${ }^{36}$ while persecution in 18th-century France was legalized through widespread court orders to hang Roma men and wilfully maim women and children. ${ }^{37}$ Ear cutting, branding, and lynching were widespread methods of marking and executing the Roma. ${ }^{38}$ A more recent example of systematic persecution that led to planned extermination of great swaths of the Roma population was the Holocaust during the Second World War, and "mass internment of Roma at Camps in Dusseldorf, Buchenwald, Auschwitz and elsewhere began in 1940, a period known as the Porajmos (the Romany word for 'the Devouring')." 39 "Over the course of the war estimates of Roma deaths range between 0.5 and 1.5 million, representing $70-80 \%$ of their European population," 40 a staggering percentage indicative of purposeful ethnic cleansing. The Czech and Moravian Roma were essentially annihilated during the Second World War, ${ }^{41}$ and the total loss of life in the Czech Republic and Slovakia was approximately 250,000 persons. After the war and in the rise of Communism in Eastern Europe behind the
Iron Curtain, there appears to have been a suppression of direct attacks against the Roma. However, the Roma were forced to give up their livelihoods and homes in order to participate in the communist system and assimilate to the wider society. ${ }^{42}$ In what can be termed an attempted cultural genocide via assimilation, the reshaping of "Gypsy behaviour" 43 in the long-range assimilation plans of the Communist Party resulted in active destruction of Roma settlements, creation of circumscribed Roma-only neighbourhoods, censorship of civil liberties, and the implementation of Special Schools for Roma. ${ }^{44}$ After the fall of the USSR in 1989, attacks against the Roma have intensified, and "today, most Roma have abandoned their traditional way of life and are concentrated in low-income housing developments of outright ghettoes throughout Europe." 45 The continued persecution hinges on the perception that Roma are racially distinct, which has been cemented in the rise of neo-Nazism and right-wing fascist groups, especially in Hungary and Slovakia. This rise in right-wing fundamentalism routinely precipitates in violent acts against Roma in segregated Roma neighbourhoods, both by non-Roma individuals as well as states as a whole, ${ }^{46}$ in the forms of shooting, stabbing, verbal and sexual assaults, and organized anti-Roma demonstrations, as well as the geographic segregation and racism in state institutions. As recently as 22 April 2012, ROMEA, the Roma media consortium in the Czech Republic reported on a neo-Nazi rally in the Czech town of Břeclav that gathered upwards of 2000 people chanting slogans such as "Where are those whores?" "Gypsies, you've fucked up," and "Let's stop gypsy terror." ${ }^{7}$ Also, on 4 May 2012 ROMEA reposted that in late April, a young Roma man was killed with a crossbow shot to the head as the attacker shouted, "You black whores, I'll kill you!" near Ostrava, Czech Republic. ${ }^{48}$ Sadly, these attacks are not restricted to the Czech Republic but have been widely reported on by Amnesty International and Human Rights Watch as occurring in many Eastern European states.

Notably, there have been the disturbing allegations of forced sterilization of Roma in Bulgaria, Hungary, Romania, Czech Republic, and Slovakia, which has been classified by the Czech Republic Defender of Rights as "without hesitation ... a technique on the verge of meeting the attributes of a genocide." 49 In addition, the more systematic persecution and structural violence perpetrated against the Roma is evident in educational segregation, where children at the primary and secondary level are separated on the basis of their racialized categories into Roma and non-Roma (white) classrooms and schools. It is also evident in the presence of separate hospital wards for whites and Roma. ${ }^{50}$ These reactions against the Roma have been construed as 
a profound "anti-gypsiism" 51 that permeates all facets of daily life. France began expelling Roma citizens from its jurisdiction in 2009, with Italy following in 2011. ${ }^{52}$ Notably, most of the countries that have been enforcing such policies are part of the European Union, which is capitalized on by the Canadian government and used to argue that these countries are democratically sound and therefore cannot be producing legitimate refugees. ${ }^{53}$ Nonetheless, an official statement made by the European Union Agency for Fundamental Rights states that "segregation [of the Roma] is still evident in many EU member states, sometimes as a result of deliberate government policy." 54

Thus, as a reaction to widespread racism, segregation, and the recent rise in persecution, Roma citizens of the European Union have been seeking refuge in other countries around the world. In fact, the Roma are not newcomers to Canada, and groups of Roma have been settled here since mid-19th century. ${ }^{55}$ Especially during the Cold War, many Roma arrived in Canada as political dissidents and were welcomed with open arms as Czech, Slovak, or Hungarian nationals, not as ethnic Roma. As Lee argues, it is very difficult to ascertain Roma-specific immigration, as Roma ethnicity was not recorded, and there was also widespread reluctance to identify as Roma. ${ }^{56}$ According to Lee, "overall the Roma population in Canada is estimated to be at least 80000, , 57 with over 90 per cent of Roma residing in the Greater Toronto Area in Ontario. ${ }^{58}$ There has been steady migration to Canada through the 1990s and 2000s, and as persecution of the Roma continues to be a daily reality in Europe, Roma asylum claims will continue to be made.

While Canada presents itself as a benevolent nation welcoming newcomers and refugees with open arms, it has a long and troubled history of excluding undesirable migrants. The recent onslaught of Conservative rhetoric concerning "bogus" and "fraudulent" refugees attacking Canada's shores and taking advantage of its liberal social policies is not new. ${ }^{59}$ It is important to consider that while the current rhetoric employed by the Conservative government is problematic, it is historically situated and is by no means the only rhetoric that has been promulgated by Canadian immigration and refugee policy throughout its history. Importantly, the actual total numbers of asylum claimants arriving at Canada's shores are rather small, and Canada is not dealing with waves or floods of claimants who are here to take advantage of the refugee system. The total number of asylum seekers has not been increasing significantly but has been hovering between 33,970 in $2009,22,543$ in 2010, 24,981 in 2011 , and 20,223 in $2012 .{ }^{60}$

\section{The Treatment of Czech Roma in Canadian Legislation}

The treatment of Czech Roma refugee claimants has been particularly problematic in the securiticization of recent Canadian responses to this group. The visa imposition throughout the last 15 years on this group of refugee claimants is explored in greater detail by Lefebvre ${ }^{61}$ and LevineRasky, St. Clair, and Beaudoin, ${ }^{62}$ but in brief, visas for Czech travellers were first imposed in 1998 to stem the large numbers of Roma making refugee claims in Canada. However, numbers of refugee claims actually rose after the imposition of the visa, ${ }^{63}$ as a result of the rise of overt post-Communist anti-Roma sentiments, by neo-Nazi groups as well as by the general populace. The visa requirement was then lifted in November 2007. The Czech Republic joined the European Union on 1 May 2004 and held the European Union presidency in the first half of 2009. Thus, the onus was on Canada to treat all European Union member states equally ${ }^{64}$ and the visa requirement was subsequently dropped for a year and a half, only to be reinstated on 13 July 2009, to much outrage by the Czech government. However, the Canadian government explained their strategy of visa requirements on Czech nationals as a way to avoid bogus refugee claimants who abuse the refugee system. ${ }^{65}$ Minister Kenney in particular stated that "the refugee claimants from Czechs make no sense because they could easily move to twenty-six other Western democracies in the European Union." 66 The rhetoric of the abuse of Canada's immigration system, and of the Roma as queue jumpers who are clogging up the asylum system, was bolstered by the Immigration and Refugee Board (IRB) 2009 Czech Fact-Finding Mission Report on State Protection, ${ }^{67}$ which has since been used to refute 90 per cent of Roma cases that come before the IRB. ${ }^{68}$ It should be noted that this report is missing from the public record and the follow-up 2011 report based on a Canadian delegation to the Czech Republic to determine country conditions has not been published. However, Citizenship and Immigration Canada itself has stated that "the imposition of visas on the Czech Republic and Mexico ... [protects] the integrity of the asylum program" in Canada ${ }^{69}$ and is necessary to deter fraudulent refugees from coming to Canada. Interestingly, as of 14 November 2013, Citizenship and Immigration has announced that all visa requirements have been lifted from the Czech Republic. As Chris Alexander, the new minister of citizenship and immigration stated, "Our confidence in lifting the visa requirement is further enhanced by Canada's improvements to its asylum system, which will serve as an effective deterrence against unfounded asylum claims."70 With Roma asylum seeker numbers dropping and Canada's economic relationship strengthening with the European Union, it remains to be seen what rhetoric will be put out 
once statistics become available for the 2013 IRB refugee determination rates from the Czech Republic.

\section{Bill C-31 and the "Bogus" Roma Refuge}

Tabled on 16 February 2012 and known as the Protecting Canada's Immigration System Act, Bill C-31 came into force on 15 December 2012. Bill C-31 is an amalgamation of two previous bills (Bill C-11 and Bill C-4), whose hardline natures have been subsumed in Bill C-31's new provisions, which have been presented as necessary in order to speed up Canada's refugee determination system and erase the massive backlog of refugee claimants. On 9 May 2012 the Conservative government introduced amendments to Bill C-31, which have the detention period for "irregular" migrants. ${ }^{71}$ However, the other problematic provisions that affect Roma refugee claimants in particular were not amended before the bill became law. The overarching argument held by the Government and Citizenship and Immigration Canada is that "Canada's asylum system is broken ... Canada's existing asylum system is crippled by an ever-increasing number of new unfounded claims," 72 which must be rooted out and removed.

In brief, the bill ${ }^{73}$ introduces numerous problematic changes to Canada's immigration and refugee policy: the barring of persons who have been convicted of a crime punishable by 10 or more years in prison, which can exclude political prisoners and activists (sections 101.2.a and 101.2.b); the revocation of permanent residence and the cessation of refugee status (sections 40.1 and 108.2); the creation of a category of designated foreign nationals (sections 95.1 and 20.1) who will be ineligible for permanent residency status for five years after their hearing based on their "irregular" means of arrival (section 20.2). There is also the linkage between the terminology of "irregular arrival" and smuggling (sections 20.1.1a and b); mandatory arrest and detention of designated foreign nationals over the age of 16 (section 3.2a and b); as well as vague and obscure ministerial powers such as in designating inadmissible foreign nationals and the imposition of conditions by the minister (sections 25.3.1) and ministerial intervention at any time during the appeal process, which is to be set up at the Immigration and Refugee Board (section 110.1). However, the most problematic provision for the Roma claimants from Eastern Europe is the ministerial power in creating designated countries of origin, or "safe" countries. Refugee claims from spontaneous asylum seekers who arrive from these designated countries of origin will run on different, much shorter timelines than the rest of the refugee determination process (section 109.1). At the time of writing, section 109.1.1 of Bill C-31 amends section 12 of the current Balanced Refugee Reform Act, stating:
109.1 (1) The Minister may, by order, designate a country, for the purposes of subsection 110(2) and section 111.1.

(2) The Minister may only make a designation

(a) in the case where the number of claims for refugee protection made in Canada by nationals of the country in question in respect of which the Refugee Protection Division has made a final determination is equal to or greater than the number provided for by order of the Minister,

(i) if the rate, expressed as a percentage, that is obtained by dividing the total number of claims made by nationals of the country in question that, in a final determination by the Division during the period provided for in the order, are rejected or determined to be withdrawn or abandoned by the total number of claims made by nationals of the country in question in respect of which the Division has, during the same period, made a final determination is equal to or greater than the percentage provided for in the order, or ...

(b) in the case where the number of claims for refugee protection made in Canada by nationals of the country in question in respect of which the Refugee Protection Division has made a final determination is less than the number provided for by order of the Minister, if the Minister is of the opinion that in the country in question

(i) there is an independent judicial system,

(ii) basic democratic rights and freedoms are recognized and mechanisms for redress are available if those rights or freedoms are infringed, and

(iii) civil society organizations exist.

Claimants who fall under the subsection of designated countries of origin have 15 calendar days to gain access to and retain counsel if they have the means to do so, file their Basis of Claim form and all supporting documents, which have to be translated. They also do not have access to the newly created Refugee Appeal Division and can rely only on judicial review of their IRB decisions. Groups such as CCR and CARL have released official statements underlining that these timelines in section 109.1.1 are not realistic and will lead to less representation by counsel and more cases being denied. ${ }^{74}$ Importantly, section 109.1 of the bill stipulates that such designations will be under the sole discretion of the minister, based on specific country of origin reports, such as the IRB Czech Fact-Finding Mission Report on State Protection. ${ }^{75}$ The country will be designated as a whole, with no provisions made for regional differences. These designated or safe countries of origin are ones that supposedly "do not normally produce refugees, have a robust human 
rights record and offer strong state protection ... to their citizens."76 Nevertheless, denying refugee claimants from these countries a fair determination process undermines Canada's refugee policy much more that the supposed influx of "bogus" refugees jumping queues. Presupposing that entire countries can be designated as "safe" fails to recognize the heterogeneity of experience in any nation, based on a person's age, geographic location, sexual orientation, ethnic background, and myriad other factors. To presume that an entire country can be designated as "safe" for all groups is profoundly reductionist and allows for entire groups of refugee claimants to be labelled as "frauds" on the basis of hailing from a Designated Country of Origin.

\section{Government Statements and Media Portrayals Surrounding Bill C-31}

Since tabling Bill C-31 in February 2012, the Conservative Government has used the media in strategic ways in order to capitalize on the "bogus refugee" imagery. "To be blunt, Canada's asylum system is broken," Minister Kenney told reporters immediately after tabling the bill on 16 February 2012. "[The previous] Act went a long way to addressing problems in our system, but it's become clear that there are still some gaps and further reforms are needed. We need stronger measures that are closer to the original bill that we had tabled back in March of 2010."77 Government critics immediately responded and stated that the bill is a "serious step backwards,"78 and that the notion of the so-called refugee queues is "an extravagant construction"79 rooted in the government's rhetorical pursuit of fraudulent claims. In response to a piece in the Montreal Gazette from 2 March 2012 entitled "Welcome to Canada-Unless We Change Our Mind," Kenney responded, "The Protecting Canada's Immigration System Act will make our refugee system fast and fair, ensuring that bona fide refugees quickly receive Canada's protection, and that those who abuse Canada's generosity and do not require our protection are quickly removed." 80 Such rhetoric of "fairness," "generosity," and "abuse" of the system by fraudulent claimants is an undercurrent of the reforms, and these discourses are enshrined in Bill C-31 itself, with clauses such as "manifestly unfounded" claims (clause 57), or "designated foreign nationals" (clause 10). According to Kenney, the apparent dysfunction of the current asylum system must be overhauled, and special interest groups have vested interests in keeping the status quo. ${ }^{81} \mathrm{~A}$ swift response to these allegations as well as to Bill C-31 itself was mounted by a variety of these so-called special interest groups, such as Amnesty International, Human Rights Watch, Roma Community Centre, CARL, CCR, Campaign against Bill C-31, and the Canadian Civil Liberties Association, in the form of press conferences, official statements, and op-ed pieces in the popular press such as the Montreal Gazette, Embassy, ${ }^{82}$ Toronto Star, ${ }^{83}$ Global News, ${ }^{84}$ and the Huffington Post. ${ }^{85}$ The responses continued in the media, and the failure of proper investigation into "safe countries" was called into question. ${ }^{86}$

The treatment of Roma refugee claimants in particular has been problematic, as this rhetoric has worked to cement the association between the fraudulent refugee and the Roma refugee claimant. Fawn in particular examines how "Roma are iconoclastic for domestic and foreign perceptions of ... national identity." ${ }^{87}$ In particular, Kenney's rhetoric has focused on the idea that the Roma are prototypical "bogus" refugees who organize in particular ways so that they can flood the already backlogged asylum system in Canada and that their numbers have been steadily increasing from 2010 . In a 22 April 2012 National Post article, Kenney stated, "We tried to circulate brochures explaining 'This is not the way you immigrate to Canada,' and it's had no impact," adding that the flood of asylum seekers is "highly organized" and "not at all spontaneous." 88 The placement of billboards in Hungary, warning people of deportation if they come to Canada, shows just how serious the government has been in trying to limit Roma migration into Canada. ${ }^{89}$ Kenney's statements that the Czech Republic and Hungary will be placed on the "safe counties" lists and the act of placing the two countries in the top five countries assessed for increased Canadian Border Services Agency removal warrants ${ }^{90}$ further add to the idea that claimants from these countries are not bona fide refugees and are therefore subject to removal. This rhetoric is being promulgated despite the fact that refugee claimants do continue to successfully claim asylum in Canada from these countries, albeit in small numbers, as shown by recent decisions such as Rezmuvez $v$ Canada, concerning a Hungarian Roma claimant at the Federal Court of Appeal, in which the judge stated in paragraph 12 that "the Board failed to review or acknowledge the recent evidence which the applicants describe in their memorandum a follows: 'there has been a severe upswing of extremism directed against Roma and further that there is extensive evidence of the government's shortcomings in actually preventing violence against Roma.'"91

The Roma community and advocates around Canada have mobilized a fairly successful campaign against these government statements, and some have received extensive coverage in popular media. ${ }^{92}$ In particular, after parliamentary testimonies from Roma advocates and lawyers on 3 May 2012, the Tribute ${ }^{93}$ published a piece decrying the ministerial powers outlined in the proposed Bill C-31, even after the announced amendments on 9 May 2012. This piece prompted a swift response from Minister Kenney in the form of an editorial, in which he proclaimed that he is 
not destroying the immigration and refugee system as had been stated. According to Kenney, "We are strengthening our system by cracking down on the abuse of Canada's generosity by human smugglers, bogus asylum claimants, fake immigration marriages, crooked immigration consultants and immigration queue-jumpers ... Canada's immigration and refugee system is the most fair and generous in the world, and will continue to be so under the new, improved system. Overheated, ideological rhetoric from special interest groups does a great disservice to Canada's tradition of openness and generosity." 94

This idea that Canada's refugee determination system is fair, just, and generous does not match the provisions set out in Bill C-31, which will negatively affect certain groups of asylum seekers, essentially shutting them out of the same timelines afforded to other claimants and discriminating against them on the basis of their country of origin. ${ }^{95}$ However, since the Roma fit the prototypical figure of the "bogus" refugee so well, it becomes easier to justify denying them the same process that other asylum seekers will be given under the guise of protecting Canada's refugee system from people who are known frauds. ${ }^{96}$ Using such inferences to bolster government reform in times of decreasing national security, unstable economic climates, and fears of border infiltration and terrorism works to justify increasing state interventions and the performance of sovereign power, under the discourse of welcoming certain people and shutting out others, whose exclusion is useful for these state projects. It would appear that for current immigration officials, "none is too many" 97 when processing Roma refugee claims from the Czech Republic and the rest of Europe.

\section{State Performativity and Discourses on Refugees: Times of Exception and Exceptional Times}

The rhetoric of the "bogus" refugee acts as a catalyst for legislative change and shows its profound impact on the creation of a binary between the "deserving good refugees" versus the "irregular uncontrollable asylum seekers," who are constructed to represent threats to sovereign borders and the nation state. In this light, the concept of state performativity is useful when analyzing recent changes made to the Canadian refugee determination system in the quest to root out all allegedly manifestly unfounded and fraudulent claims. The newly implemented Bill C-31 bolsters the potent discourses of "fraud" and of the "bogus" refugees threatening Canada's borders that are present in the rhetoric of Minister Kenney and the Canadian Conservative Government. ${ }^{98}$ According to the government, the apparent dysfunction of the current asylum system must be overhauled, and special interest groups have vested interests in keeping the status quo. ${ }^{99}$
Such movements point to the weakening of state sovereign power and the need to perform in spectacular ways, in order to bolster state influence and work towards nation-building projects. In particular, the creation of abject Others works to police and discipline the wider populace, ${ }^{100}$ and it also justifies a crusade against the created common enemies that are alleged to threaten our established ways of life. In particular, "the accumulation of affective value shapes the surfaces of bodies and worlds"101 and creates a world order in which it is perfectly justified to unilaterally decide who is a fraud or a terrorist and therefore inadmissible to our countries. As Butler argues, in times when sovereignty is threatened, "the law is suspended in the name of the 'sovereignty' of the nation, where 'sovereignty' denotes the task of any state to preserve and protect its own territoriality." 102 The state does this by detaining those that have been deemed a threat, as well as denying them due process and fair judicial review. With the creation of the Designated Countries of Origin in Bill C-31 and by making it very difficult to file a claim under the new timelines, certain groups of asylum seekers will be excluded from the system and returned to their countries of origin, under the rhetoric of unclogging Canada's refugee system from persons about whom it is already known that they are fraudulent refugees. ${ }^{103}$

In this focus on the constructed binary between the "good refugee," who remains in a refugee camp until selected and resettled in Canada, versus the "fraudulent, queuejumping asylum seeker," the concept of Agamben's inclusive exclusion ${ }^{104}$ continues to inform how we divide and separate ourselves from others. As Hansen and Stepputat posit, these formulations are centred on "the figure, the outlaw, the Friedlos, or the convict, [who] was historically the symbol of the outside upon whose body and life the boundaries of the political community could be built."105 The concretization of certain bodies into the abject Others justifies increasingly draconian ranges of intervention, not only in material realms but also in the discourses used in the justification of terror, incarceration, and violence against these abject bodies. In particular, the naturalizing of differences and the intensification of violence perpetrated against certain bodies has been seen as just and justified in the violent responses to the 9/11 attacks, whether against the Muslim terrorist or the asylum seeker threatening sovereign borders. The need to protect the threatened sovereignty of a Western nation against the attacks of the terrorists, both from the outside and in our midst, creates regimes that rationalize state interventions in a climate of fear. For the current Canadian government, a powerful symbol in vogue is the "bogus refugee."

As state sovereignty becomes more contested, the "precarious construction and maintenance of localized sovereign 
power through exercise of actual and 'spectral' violence, transmitted through rumours, tales, and reputations"106 exhibits a peculiar paradox. On the one hand, sovereign borders are becoming much more flexible and porous, with slippages and frictions in the intersections of the global and the local. On the other, in an effort to counteract this phenomenon, governments are moving to more rigid regimes of control and toward an ossification of specific enemy figures into easily understandable and predictable depictions. The border is construed as a concrete thing, regardless of its inherent porosity, adding yet more ammunition to the rhetoric of illegal border crossing and of fraudulent asylum seekers looking to fleece the benevolent Canada. In the recent growth of cross-border migration management, certain mobilities are made legitimate while others are made abject. ${ }^{107}$ The authority of the state and its legitimacy must be cleverly manufactured and constantly supported, ${ }^{108}$ and the border is a particular locale where sovereignty intersects with notions of threat, security, and power. Certain bodies thus become "the agents of governmentality,"109 and the bodies of the asylum seeker must therefore be controlled, managed, and used in the performance of sovereignty and security at the border and beyond.

Importantly, as Andreas reminds us, "public perception is powerfully shaped by the images of the border which politicians, law enforcement agencies, and the media project." 110 The figure of the outlaw, the abject Other, the Roma refugee claimant, is lambasted and paraded for the citizenry to see, a sombre reminder not to be like them in order to keep the already fraying fabric of sovereignty together in these trying, terror-ridden times. Such spectacles of means, whether in the creation of extra-legal immigration detention facilities, extraordinary rendition, or draconian legislation, make clear "the insistence on a power that must be displayed." 111 In looking for "fraudulent" asylums seekers, there is a profound reaffirmation of borders and the need to strengthen sovereignty in these uncertain times. ${ }^{112}$ In addition, Buck-Morss posits that the particularly powerful trope of Western innocence construes the benevolent nation as being under threat by outside tides and waves of irregular migrants, terrorists, and human smugglers. ${ }^{113}$ Interventions against terrorists and "fraudulent" asylum seekers become justified in the creation of a climate in which the very fabric of social life is under threat at the hand of the abject Other. The Roma come to stand in for the dangerous migrant who is lazy and ungovernable, one who has come to take advantage of Canada's generosity. The Roma continue to assault Canada's borders with a steady persistence, so the state creates legal barriers that facilitate faster determination of unfounded and "bogus" claims and sure deportation back to Europe. The Roma do not fit into the conception of the modern Canadian state, and as Aiken has argued, the undesirable migrant Other is seen as dangerous to sovereignty. ${ }^{114}$

Further, the creation of a particular form of "we" gives rise to the justification of the attacks on refugees on the grounds of humanity and the necessity to uphold and fight for ideals, such as enduring freedom and democracy. ${ }^{115}$ The integrity of what it means to be part of the Western world, and what it may mean to be Canadian, is viewed to be under attack by those who are not with us but against us. As Vertovec argues, "Civil servants and politicians reflect, draw on, or manipulate popular notions of national versus alien culture to develop policies and manage state institutions ... the issues surrounding migration stimulate, manifest, and reproduce cultural politics." 116 Thus, as frontiers become blurred and borders become untied from specific geopolitical locales, media representations bolster the state ideology and discourses, especially if the state is adept at tapping into cultural fears about a particular abject group. If the government can prove that the Roma do not have a real, legitimate basis on which to structure their refugee claim, why should they then come and take advantage in Canada? In Canada, "bogus" refugees are construed as not only undermining Canada's refugee determination system but also as posing a threat to a labile and easily disturbed economic equilibrium. The government capitalizes on the trope of the immigrant as the one who steals our jobs and takes advantage of the welfare state at the "proper" citizens' expense. ${ }^{117}$

Affective responses lie at the heart of the discourses and rhetoric that is being used to mobilize popular beliefs and bolster cultural constructions of our perceived enemies in the performance of state sovereignty and the justification of the control and expulsion of certain bodies. The concretization of borders, and the hyping up of border anxieties, as well as designating which bodies matter and who the perceived enemies are, is a very affective and millennial phenomenon, one that speaks to our hopes and fears in an unstable and shifting world. As Ahmed ${ }^{118}$ cogently explores, emotions align with particular bodies, and affect sticks in very particular ways to those that have been constructed as useful in bolstering regimes and creating truths about the enemies around us. In immigration policy and the ever-present discourse of fear and threat of being overrun by undocumentable asylum seekers, Ahmed also points out that "the figure of the bogus asylum seeker is detached from particular bodies: any incoming bodies could be bogus, such that their 'endless' arrival is anticipated as the scene of 'our injury."'119 Thus, we are constantly waiting for the bogus claimants to arrive, ready to interrogate them and prove their fraud in the crusade to protect Canadian refugee determination system from the waves of "bogus" refugees, because even 
before they arrive and file a refugee claim, we already know that they are a fraud, and it is only a matter of time before they will be found out and removed. 120

Importantly, since any body can be a threat, these objects of fear and dread become interchangeable for one another. ${ }^{121}$ Thus, the Muslim terrorists become the immigrants who steal our jobs and make our pensions harder to get in these trying neo-liberal times, and in turn they become the fraudulent asylum seekers jumping queues and taking advantage of Canada. Such narratives of fear become the narratives of possibility, installing particular truths and regimes of governance. It is the not-yet-ness of feared bodies, ${ }^{122}$ the uncontrollable nature of the threat that is the most potent. Immigrants and asylum seekers are dangerous because they are hard to control and thus must be detained and managed. We can never be sure of exactly when the asylum seeker arrives, and that uncertainty creates much anxiety in the state apparatus of the border. There is a profound fear of mobility and of the uncontrollable because "the asylum seeker is 'like' the terrorist, an agent of fear, who may destroy 'our home."' 123 Such notions of an injury to the nation manifests in Canada through our "concern about cultural identity and cultural loss, the fear that someone is robbing us of our culture and that [our] authenticity will be destroyed." 124 The particular flavour of millennial apocalypticism that manifests in these fears is seen to be solvable only through strict policing and discipline of the abject. Thus, the paranoia and states of emergency organize and control the unclean, uncontrollable, dangerous, and disruptive bodies. ${ }^{125}$ The theatre of conspicuous performance of power manifests in the equating on one particular group of asylum seekers to being dangerous, fraudulent, and unwelcome, in a high-profile spectacle of government power through new legislation, "safe country of origin" lists, and official government statements. Thus, the performance of state sovereign power, which is implicit in Canada's Bill C-31, is contingent on the spectacle of capitalizing on the affective responses to rhetoric of "fraud" and of "bogus" refugees threatening to invade our borders and destroy our Canadian identity and way of life.

\section{Conclusions}

With the 16 February 2012 introduction and 15 December 2012 implementation of Bill C-31, profound changes to Canada's immigration and refugee policy have come swiftly. I have argued that the particular discourses of "fraud" and "bogus" that underpin the supposed need for this harsher legislation stem from the increased precarity of sovereign power, as the nation must perform a particular spectacle in order to maintain its authority and control. The asylum seeker comes to embody the ultimate threat to Canada the
Benevolent, and if they make it past the increasing deterrents along the way to asylum, they must be dealt with swiftly, whether by being turned away at the border, expedited through the asylum process, or incarcerated in detention centres or even geographically removed locales. The restructuring of Canada's refugee regime will have lasting repercussions for those fleeing persecution and wishing to find a safe haven in Canada. The case of Roma asylum seekers is particularly cogent as the Roma have come to embody the "fraudulent" and "bogus" refugee coming to take advantage of the Canadian welfare state. With asylumseeker and government-assisted refugee numbers dropping, the current Conservative government of Canada has used the Roma to bolster their ideologies about which refugees are wanted and have argued that it is precisely because of the bogus refugee that further reforms to the Canadian immigration and refugee system are needed. It is important to stress that the purpose of this article is not to vilify the current Conservative government, as, throughout history, Canada has had rather harsh immigration regimes, regardless of the political party in power. However, what is very clear about Bill C-31 is that the hard-line measures it introduces presuppose which refugee claimants are the proper refugees who are welcome and which ones are inherently "fraudulent" and must be dealt with accordingly. Such presuppositions are not in accordance with international law, and Canada appears to be shirking its responsibility to provide due process to persons seeking asylum at its borders. It remains to be seen whether Bill C-31 will withstand impending Charter challenges ${ }^{126}$ and whether it will be deemed constitutional to deny a person asylum on the basis of the discretion of someone like Minister Kenney and his apparently keen ability to pick out the bogus among the masses.

\section{Notes}

1. Audrey Macklin, “Disappearing Refugees," Columbia Human Rights Law Review 36 (2005): 101-61.

2. Stéphane Lefebvre, "Recent Research: Roma and the Czech-Canadian Visa Issues, 1998-9," Contemporary Politics 9, no. 3 (2003): 313-22.

3. Will Guy, "No Soft Touch': Romani Migration to the UK at the Turn of the 21st Century," Nationalities 31, no. 1 (2003): 63-80.

4. Lisa H. Malkki, "National Geographic: The Rooting of Peoples and the Territorialisation of National Identity among Scholars and Refugees," Cultural Anthropology 7, no. 1 (1992): 24-44. Also Malkki, "Citizens of Humanity: Internationalism and the Imagined Community of Nations," Diaspora: A Journal of Transnational Studies 3, no. 1 (1994): 41-68; Malkki, Purity and Exile: Violence, 
Memory, and National Cosmology among Hutu Refugees in Tanzania (Chicago: Chicago University Press, 1995); Malkki, "Refugees and Exile: From 'Refugee Studies' to the National Order of Things," Annual Review of Anthropology 24 (1995): 493-523; Malkki, "Speechless Emissaries: Refugees, Humanitarianism, and Dehistoricization," Cultural Anthropology 11, no. 3 (1996): 377-404; Malkki, Improvising Theory: Process and Temporality in Ethnographic Fieldwork (Chicago: University of Chicago Press, 2007).

5. Christina Clark-Kazak, Recounting Migration: Political Narratives of Congolese Young People in Uganda (Montreal and Kingston: McGill-Queen's University Press, 2011).

6. Wenona Giles and Jennifer Hyndman, eds., Sites of Violence: Gender and Conflict Zones (Berkeley: University of California Press, 2004).

7. Jennifer Hyndman, "Second-Class Immigrants or FirstClass Protection? Resettling Refugees to Canada," in Resettled and Included? Employment Integration of Refugees, ed. P. Bvelander, H. Hagstrom, and S. Ronnqvist, 247-65 (Malmo: Malmo University, 2009).

8. Daphne Winland, "We are now a nation": Croats between "Home" and "Homeland" (Toronto: University of Toronto Press, 2007).

9. M. Billig, Banal Nationalism (London: Sage, 1995).

10. M. Gullestad, Plausible Prejudice: Everyday Experiences and Social Images of Nation, Culture and Race (Oslo: Universitetsforlaget, 2006.

11. Steven Vertovec, "The Cultural Politics of Nation and Migration," Annual Review of Anthropology 40 (2011): 241-59.

12. C. Brambilla, "Borders Still Exist! What Are Borders?", in Transnational Migration, Cosmopolitanism and Dis-located Borders, ed. B. Riccio and C. Brambilla, 73-85 (Rimini: Guaraldi, 2010). Also M. Kearney, "The Classifying and Value-Filtering Missions of Borders," Anthropology Theory 4, no. 2 (2004): 131-56.

13. N. P. De Genova, "Migrant 'Illegality' and Deportability in Everyday Life," Annual Review of Anthropology 31 (2002): 419-47. Also P. Vila, ed., Ethnography at the Border (Minneapolis: University of Minnesota Press, 2003); J. Heyman, "Ports of Entry as Nodes in the World System," Identities 11 (2004): 303-27; S. B. Coutin, Nations of Emigrants: Shifting Boundaries of Citizenship in El Salvador and the United States (Ithaca, NY: Cornell University Press, 2007); A. S. Camacho, Migrant Imaginaries: Latino Cultural Politics in the U.S.-Mexico Borderlands (New York: New York University Press, 2008); K. M. Donato, B. Wagner, and E. Patterson, "The Cat and Mouse Game at the Mexico-U.S. Border: Gendered Patterns and Recent Shifts," International Migrant Review 42 (2008): 330-59; A. Linde-Laursen, Bordering: Identity Processes between the National and Personal (Farnham, UK: Ashgate, 2010); C. Radu, "Beyond Border-'Dwelling': Temporalizing the Border-Space through Events," Anthropology Theory 10, no. 4 (2010): 409-33; B. Riccio and C. Brambilla, eds., Transnational Migration,
Cosmopolitanism and Dis-Located Borders (Rimini, Italy: Guaraldi, 2010).

14. In the 9 May 2012 amendments to Bill C-31, the 12-monthlong mandatory detention period for "irregular arrivals," a category designated by the minister, has been lessened to 14 days with review, after which review will be conducted every 180 days. Groups such as Canadian Association of Refugee Lawyers (CARL) and Canadian Council for Refugees (CCR) continue to maintain that detaining asylum claimants purely on the basis of their means of arrival for any length of time is unconstitutional and contrary to section 7 of the charter.

15. J. Blommaert, "Language, Asylum, and the National Order," Current Anthropology 50, no. 4 (2009): 415-41. Also J. X. Inda, Targeting Immigrants: Government, Technology, and Ethics (Oxford: Blackwell, 2006); Michel Foucault, "Governmentality," in The Foucault Effect, ed. Graham Burchell, Colin Gordon, and Peter Miller, 87-105 (Chicago: University of Chicago Press, 1978); Foucault, Two Lectures, Power/ Knowledge: Selected Interviews \& Other Writings, 19721977, ed. Colin Gordon, 78-108 (New York: Pantheon Books, 1980).

16. Vertovec, "Cultural Politics of Nation and Migration." For racialization of the immigrant category, see P. A. Silverstein, "Immigrant Racialization and the New Savage Slot: Race, Migration, and Immigration in the New Europe," Annual Review of Anthropology 34 (2005): 363-84.

17. Arturo Escobar, "Identity," in A Companion to the Anthropology of Politics, ed. D. Nugent and J. Vincent, 248-66 (Oxford: Basil Blackwell, 2004). Also C. B. Brettell, "Theorizing Migration in Anthropology: The Social Construction of Networks, Identities, Communities and Globalscapes," in Migration Theory, ed. C. B. Brettell and J. F. Hollifield, 97-135 (New York: Routledge, 2000); A. Linde-Laursen, Bordering: Identity Processes between the National and Personal (Farnham, UK: Ashgate, 2010); Thomas Blom Hansen and Finn Stepputat, "Introduction," in Sovereign Bodies: Citizens, Migrants, and the States in the Postcolonial World, ed. Thomas Blom Hansen and Finn Stepputat, 1-36 (Princeton: Princeton University Press, 2005); G. S. Gullette, "Migration, Transnationalism, and Belonging: Movements in the Nation-State," American Anthropology 108, no. 3 (2006): 521-4; R. Mandel, Cosmopolitan Anxieties: Turkish Challenges to Citizenship and Belonging in Germany (Durham, NC: Duke University Press, 2008).

18. Sara Ahmed, "Affective Economies," Social Text 22, no. 2 (2004): 117-39. Also Rosalind C. Morris, "Theses on the Questions of War: History, Media, and Terror," Social Text 20, no. 3 (2002): 149-75; Susan Buck-Morss, "A Global Public Sphere?, Situation Analysis 1 (2002): 10-19; Étienne Balibar, "Violence and Civility: On the Limits of Political Anthropology," Differences 20, nos. 2-3 (2009): 9-35; Kathleen Stewart and Susan Harding, "Bad Endings: American Apocalypse," Annual Review of Anthropology 28 (1999): 285-310. 
19. See Victoria Esses, Stelian Medianu, and Andrea Lawson, "Uncertainty, Threat, and the Role of the Media in Promoting the Dehumanization of Immigrants and Refugees,' Journal of Social Issues 69, no. 3 (2013): 518-36.

20. Ian Hancock, The Pariah Syndrome (Ann Arbor, MI: Karoma Publishers, 1987). Also Hancock, We Are the Romani People (Hertfordshire, UK: University of Hertfordshire Press, 2002).

21. Ronald Lee, "Post-Communist Roma Migration to Canada," Cambridge Review of International Affairs 13, no. 2 (2000): 51-70. Ronald Lee, The Living Fire (Montreal: Tundra Books, 2009). Also Lee, "A New Look at Our Roma Origins and Diaspora," Roma Community Centre, http://www .romatoronto.org/pdf/Roma_Origins-RonaldLee.pdf.

22. Christine Walsh and Brigette Krieg, "Roma Identity: Contrasting Constructions," Canadian Ethnic Studies 39, nos. 1-2 (2007): 169-86.

23. Julianna Butler, "Contested Histories and Identities: Romani Refugees in Toronto" (MA thesis, University of Western Ontario, 2009).

24. Jacqueline Bonisteel, "Ministerial Influence at the Canadian Immigration and Refugee Board: The Case for Institutional Bias," Refuge 27, no. 1 (2010): 103-9. Also Ronald Poulton, "Wondrous Strange: A Reply to the Myth of the Evil Refugee," Refuge 27, no. 1 (2010): 119-22; Martin Collacott, "Reforming the Canadian Refugee Determination System," Refuge 27, no. 1 (2010): 110-18; Collacott, "Collacott Response to Poulton Critique," Refuge 27, no. 1 (2010): 123-4.

25. Jamie Chai Yun Liew, "Beyond Country of Origin: Smith v. Canada and Refugees from Unexpected Places," Canadian Journal of Women and the Law 23, no. 2 (2011): 686-96.

26. Gerald Heckman, "Canada's Refugee Status Determination System and the International Norm of Independence," Refuge 25, no. 2 (2008): 79-102.

27. Gerald Kernerman, "Refugee Interdiction before Heaven's Gate," Government and Opposition 43, no. 2 (2008): 230-48.

28. Catherine Dauvergne, Humanitarianism, Identity, and Nation: Migration Laws in Canada and Australia (Vancouver, BC: UBC Press, 2005).

29. Ahmed, "Affective Economies." Also Arjun Appadurai, Fear of Small Numbers: An Essay on the Geography of Anger (Durham, NC: Duke University Press, 2006), 49-85.

30. Foucault, Two Lectures, 78-108.

31. Lee, Living Fire.

32. Aidan McGarry, "Ethic Group Identity and the Roma Social Movement: Transnational Organizing Structures of Representation," Nationalities Papers 3 (2008): 449-70. Also Dimitrina Petrova, "The Roma: Between a Myth and the Future," Social Research 70, no. 1 (2003): 111-61.

33. Ronald Lee, "A New Look at Our Roma Origins," Roma Community Centre, http://www.romatoronto.org/pdf/ Roma_Origins-RonaldLee.pdf. Also Lee, Living Fire.

34. The 1951 Geneva Convention defines a refugee as a person who is outside his or her country of nationality or habitual residence; has a well-founded fear of being persecuted because of his or her race, religion, nationality, membership of a particular social group, or political opinion; and is unable or unwilling to avail him- or herself of the protection of that country, or to return there, for fear of persecution (see Article 1A[2] Convention relating to the Status of Refugees 1951, 189 UNTA 150, Can TS no. 6 [entered into force 22 April 1954, accession by Canada 4 June 1969]).

35. Cynthia Levine-Rasky, Paul St. Clair, and Julianna Beaudoin, "The Exclusion of Roma Claimants in Canadian Refugee Policy," Patterns of Prejudice 48, no. 1 (2014): 69. Also U.S. Department of State, "2011 Human Rights Reports: Czech Republic," 2012, http://www.state.gov/j/ drl/rls/hrrpt/2011/eur/186344.htm. Also Chris Johnstone, "US Ambassador Calls for Czech Action to End Roma Exclusion, Discrimination," czechposition.com, 28 May 2012, http://www.ceskapozice.cz/en/news/politics-policy/ us-ambassador-calls-czech-action-end-roma-exclusion -discrimination.

36. Levine-Rasky, St. Clair, and Beaudoin, "Exclusion of Roma Claimants."

37. Ibid.

38. David Crowe, A History of the Gypsies of Eastern Europe and Russia, 2nd ed. (New York: Palgrave MacMillan, 2007), 37.

39. Levine-Rasky, St. Clair, and Beaudoin. "Exclusion of Roma Claimants." See also Henry R. Huttenbach, "The Roma Porajmos: The Nazi Genocide of Europe's Gypsies," Nationalities Papers 19, no. 3, (1991), 373-94.

40. Ibid.

41. Elena Marushiakova and Vesselin Popov, "Historical and Ethnographic Background: Gypsies, Roma, Sinti," in Between Past and Future: The Roma of Central and Eastern Europe, ed. Will Guy (Hatfield: University of Hertfordshire Press, 2001), 38.

42. Lee, "Post-Communist Roma Migration to Canada."

43. Crowe, History of the Gypsies of Eastern Europe and Russia, 56.

44. Ibid., 61 .

45. Levine-Rasky, St. Clair, and Beaudoin, "The exclusion of Roma claimants in Canadian refugee policy," 72.

46. Crowe, History of the Gypsies of Eastern Europe and Russia. Also Shannon Fogg, "They Are Undesirables: Local and National Responses to Gypsies during World War II," French Historical Studies 31, no. 2 (2008): 327-58; Hancock, Pariah Syndrome.

47. ROMEA, "Czech Republic: Police Prevent Neo-Nazis from Attacking Romani Residents of Břeclav," Czech Press Agency, 22 April 2012.

48. ROMEA, "Czech Republic: Cousin of Crossbow Victim Says Shooter Shouted 'You black whores I'll kill you!," Czech Press Agency, 4 May 2012.

49. Gwendolyn Albert, "Roma Face Coercive Sterilization," Infoshop News, 24 August 2007, http://news.infoshop.org/ 
article.php? story $=20070805235707645 \&$ query $=$ Roma + Face+Coercive+Sterilization .

50. In the Czech Republic: see Levine-Rasky, St. Clair, and Beaudoin, "The Roma and Canadian Refugee Policy."

51. Hancock, We Are the Romani People, 246.

52. Levine-Rasky, St. Clair, and Beaudoin, "The exclusion of Roma claimants in Canadian refugee policy 7.

53. Jason Kenney, letter to editor, Montreal Gazette, 7 March 2012. Also Kenney, editorial, Tribune, 23 May 2012.

54. European Union Agency for Fundamental Rights, Housing Conditions of Roma and Travellers in the European Union: Comparative Report (Luxembourg: European Communities, 2009).

55. Lee, Living Fire.

56. Lee, "Post-Communist Roma Migration to Canada," 60.

57. Ibid., 61.

58. Immigration and Refugee Board of Canada, Country Report: October to December 2009 and Year to Date 2009.

59. See, for example, Hyndman, "Second-Class Immigrants or First-Class Protection?"

60. Canadian Council for Refugees, Immigration and Refugee Board Statistics 2012.

61. Lefebvre, "Recent Research."

62. Levine-Rasky, St. Clair, and Beaudoin, "The exclusion of Roma claimants in Canadian refugee policy," 10.

63. Ibid.

64. Ibid., 13.

65. Ibid.; also Citizenship and Immigration Canada, "Canada Imposes a Visa on the Czech Republic," news release, 13 July 2009, http://www.cic.gc.ca/english/department/ media/releases/2009/2009-07-13a.asp.

66. CTV News Staff, "Kenney Defends Visa Rules for Czech Nationals," CTV News, 15 July 2009, http:// www.ctv.ca/CTVNews/TopStories/20090714/visas _immigration_090714.

67. Immigration and Refugee Board of Canada, Country Report.

68. Levine-Rasky, St. Clair, and Beaudoin, "The Roma and Canadian Refugee Policy."

69. Citizenship and Immigration Canada, "Annual Report to Parliament on Immigration, 2009,” http://www.cic.gc.ca/ english/resources/publications/annual-report2009/index .asp.

70. Citizenship and Immigration Canada, "News Release: Canada Lifts Visa Requirement for the Czech Republic," 14 November 2013, http://www.cic.gc.ca/english/department/ media/releases/2013/2013-11-14.

71. Previously the provision was to detain any irregular arrival 16 years or older for a minimum of one year without review: sections 49 (2)(c), 55(3.1 a,b), 56(1), 57. This has been amended to detention for 14 days followed by a review.

72. Citizenship and Immigration Canada, "Designated Countries of Origin," 2011, accessed December 2011, http:// www.cic.gc.ca/eglish.refugees/reform-safe.asp.
73. Bill C-31, An Act to Amend the Immigration and Refugee Protection Act, the Balanced Refugee Reform Act, the Marine Transportation Security Act and the Department of Citizenship and Immigration Act, first reading 16 February 2012, enforced 15 December 2012. http://parl.gc.ca/legisinfo/ BillDetails.aspx?billId=5383493.

74. Canadian Association of Refugee Lawyers, http://www .carl-acaadr.ca/; Canadian Council for Refugees, http:// www.ccrweb.ca.

75. Immigration and Refugee Board of Canada, Country Report.

76. Citizenship and Immigration Canada, "Designated Countries of Origin."

77. Dale Smith, "Analysis: Unpacking the Latest Refugee Reform Bill," Xtra, 28 February 2012.

78. Ibid.

79. Peter Showler, "Bill C-31: A Big New Refugee Bill but the Same Old Debate," Maytree Conversations, Maytree 28 February 2012, http://maytree.com/blog/2012/02/bill -c-31-a-big-new-refugee-bill-but-the-same-old-debate/.

80. Kenney, editorial, Tribune.

81. Ibid. Also Kenney, letter to the editor, Montreal Gazette, 7 March 2012.

82. Susan McGrath, "Refugee Policies Should Be Based on Fact, Not Fiction," Embassy, 14 March 2012.

83. Joe Fiorito, "Roma Refugees Have a Voice," Toronto Star, 25 May 2012. Also Nicholas Keung, "Roma Refugees: Canadian Billboards in Hungary Warn of Deportation," Toronto Star, 25 January 2013.

84. Victoria Revay, "The Harsh Realities of Being a Hungarian Roma Refugee in Canada," Global News, 8 November 2012.

85. Stephanie Silverman, "Refugees Are People Too," Huffington Post, 11 May 2012. Also Stephanie Silverman, Efrat Arbel, and Julianna Beaudoin, "Why Is There No Refuge for Roma Refugees?”, Huffington Post, 21 December 2012.

86. Karl Nerenberg, "Media and Politicians Fail to Investigate Facts about So-Called 'Safe Countries,"' rabble.ca, 28 May 2012, http://rabble.ca/blogs/bloggers/karl-nerenberg/2012/05/hill-dispatches-media-and-politicians-failinvestigate-facts-a.

87. Rick Fawn, "Czech Attitudes towards the Roma: 'Expecting More of Havel's Country'?," Europe-Asia Studies 53, no. 8 (2001): 1193.

88. Sarah Boesveld, "Efforts to Keep Bogus Roma Refugees Out Have Failed: Jason Kenney, National Post, 22 April 2012, http://news.nationalpost.com/2012/04/22/efforts-to-keep -bogus-roma-refugees-out-have-failed-jason-kenney/.

89. Nicholas Keung, "Roma Refugees: Canadian Billboards in Hungary Warn of Deportation," Toronto Star, 25 January 2013.

90. Tom Godfrey, "Beefing Up the Border Patrol," Sudbury Star, 2 April 2012.

91. Rezmuvez v Canada, Federal Court of Appeal, MCI 2012 FC 334, Para 12. (2012). 
92. Toby Cohen, "Roma Speak Out against Refugee Crackdown," Canada.com, 3 May 2012. Also CTV News Staff, "Roma Advocate Says Kenney Fanning 'Gypsy Fiction," Canadian Press, 3 May 2012, http://www.ctvnews .ca/roma-advocate-says-kenney-fanning-gypsy-fiction-1.804737. Fiorito, "Roma Refugees Have a Voice," Toronto Star, 25 May 2012; Jessica Murphy, "Roma People Not 'Bogus' Refugees: Advocates," Vancouver Sun, 3 May 2012; Karl Neremberg, Hill Dispatches, “'Never again!' (Except for the 'Gypsies'),' rabble.ca, 24 April 2012. http://rabble.ca/blogs/bloggers/karl-nerenberg/2012/04/ hill-dispatches-never-again-except-gypsies.

93. Maryanne Firth, "Minister 'Destroying Immigration and Refugee System," Tribute, 10 May 2012.

94. Kenney, editorial, Tribune.

95. Canadian Council for Refugees, http://www.ccrweb.ca.

96. Macklin, "Disappearing Refugees."

97. Andy Levy-Ajzenkopf, "Immigration Bill's Impact Cause for Concern," Canadian Jewish News, 4 June 2012.

98. See Kenney, letter to the editor, Montreal Gazette; Kenney, editorial, Tribune; CTV News Staff, "Kenney Defends Visa Rules"; Smith, "Analysis."

99. Kenney, letter to the editor, Montreal Gazette; Kenney, editorial, Tribune.

100. Foucault, Governmentality. See also Pia Zambelli, "Refugee Status Determination in Canada and the Path to Radical Reform" (PhD diss., McGill University, 2012).

101. Ahmed, "Affective Economies," 121.

102. Judith Butler, Precarious Life: Powers of Violence and Mourning (London: Verso, 2006), 55. This can also be seen in Australia's policy to excise entire coastlines from its laws in order to allow for the removal of unwanted asylum seekers to the detention facilities on Nauru. See, for example, Allison Mountz, "The Enforcement Archipelago: Detention, Haunting, and Asylum on Islands," Political Geography 30 (2011): 118-28.

103. Macklin, "Disappearing Refugees."

104. Giorgio Agamben, State of Exception (Chicago: University of Chicago Press, 2005).

105. Hansen and Steputat, "Introduction," 17.

106. Ibid., 4.
107. Louise Amoore, "Biometric Borders: Governing Mobilities in the War on Terror," Political Geography 25 (2006): 33651; M. Sparke, "A Neoliberal Nexus: Economy, Security, and the Biopolitics of Citizenship on the Border," Political Geography 25 (2006): 151-80.

108. Butler, Precarious Life.

109. Ibid., 71.

110. P. Andreas, Border Games: Policing the U.S.-Mexico Divide, 2nd ed. (Ithaca, NY: Cornell University Press, 2009), 9.

111. Rosalind C. Morris, "Theses on the Questions of War: History, Media, and Terror," Social Text 20, no. 3 (2002): 168.

112. Jake Kosek, "Ecologies of Empire: On the New Uses of the Honeybee," Cultural Anthropology 25, no. 4 (2010): 655, emphasis added.

113. Buck-Morss, "Global Public Sphere," 14.

114. Sharryn Aiken, "Of Gods and Monsters: National Security and Canadian Refugee Policy," Revue québécoise de droit international 1, no. 1 (2001): 1-51.

115. Buck-Morss, "Global Public Sphere," 16.

116. Vertovec, "Cultural Politics of Nation and Migration," 242.

117. Kenney, letter to the editor, Montreal Gazette; Kenney, editorial, Tribune

118. Ahmed, "Affective Economies."

119. Ibid., 123, emphasis added.

120. Also Macklin, "Disappearing Refugees."

121. Ahmed, "Affective Economies," 127.

122. Ibid., 135.

123. Ibid., 136.

124. R. Grillo, "Immigration and the Politics of Recognizing Difference in Italy," in The Politics of Recognizing Difference: Multiculturalism Italian-Style, ed. Ralph Grillo and Jeff Pratt (Aldershot: Ashgate, 2002), 23.

125. Ibid., 298.

126. "Legal Challenge to Refugee Health Care Cuts Begins Today," Canadian Association of Refugee Lawyers, 17 December 2013, http://www.carl-acaadr.ca/articles/61.

Petra Molnar Diop is completing a Juris Doctor degree at the Faculty of Law at the University of Toronto. The author may be contacted at petramdiop@gmail.com.

(C) Petra Molnar Diop, 2014. This open-access work is licensed under a Creative Commons Attribution-NonCommercial 4.0 International License, which permits use, reproduction and distribution in any medium for non-commercial purposes, provided the original author(s) are credited and the original publication in Refuge: Canada's Journal on Refugees is cited. 